\title{
Digestion of dry and high-moisture maize diets in the stomach of the pig
}

\author{
BY J. H. G. HOLMES*, H. S. BAYLEY AND F. D. HORNEY, \\ Departments of Nutrition and Clinical Studies, University of Guelph, \\ Guelph, Ontario, Canada
}

(Received 30 April 1974-Accepted I3 June 1974)

\begin{abstract}
1. Pigs were fitted with re-entrant duodenal cannulas anterior to the pancreatic duct, and total collections of digesta were made for $12 \mathrm{~h}$ periods.

2. Maize-soya-bean diets were made from maize which had been harvested with a drymatter content of $770 \mathrm{~g} / \mathrm{kg}$ and either dried, preserved with acetic or propionic acid or ensiled naturally. The pigs received two meals of these diets/d at $\mathrm{I} 2 \mathrm{~h}$ intervals, and the amount of digesta flowing through their cannulas was measured.

3. Between 4.5 and $5.25 \mathrm{l}$ of digesta flowed through the cannulas in the $12 \mathrm{~h}$ collection period, 0.9 of the total $12 \mathrm{~h}$ flow passed through the cannulas in the first $9 \mathrm{~h}$ with the drymaize diet and 0.8 with the acid-treated-maize diets.

4. The mean total dry matter intake was $358 \mathrm{~g} / \mathrm{meal}$, and $304 \mathrm{~g}$ dry matter passed through the duodenal cannulas in the $12 \mathrm{~h}$ collection period. The corresponding intake and flow of nitrogen $(\mathrm{g} / \mathrm{I} / \mathrm{h}$ ) was $\mathrm{II} \cdot \mathrm{I}$ and $9 \cdot 6$, and for chromic oxide $\mathrm{I} \cdot \mathrm{I} 3$ and $0 \cdot 94$.

5. The pigs consumed $205 \mathrm{~g}$ starch (total $\alpha$-linked glucose polymers)/meal, and I.5 $\mathrm{g}$ free glucose/meal. Only I $10 \mathrm{~g}$ starch and $4 . \mathrm{I} \mathrm{g}$ free glucose reached the duodenal cannulas, suggesting that digestion and absorption of up to $92 \mathrm{~g}$ glucose had taken place anterior to the pancreatic ducts.
\end{abstract}

Maize harvested with a high moisture content can be dried, naturally ensiled or preserved by the addition of organic acids such as acetic or propionic acids. Digestion of diets made from samples of maize preserved in this way has been investigated by using normal pigs (Bayley, Holmes \& Stevenson, I974) and pigs fitted with re-entrant ileal cannulas (Holmes, Bayley \& Horney, 1973). The diets containing maize preserved with organic acids had the higher digestibilities; more starch and nitrogen of the diets containing the organic acid-treated maize were digested in the small intestine than of the diets containing dry maize.

The object of this study was to compare the digestion of diets containing the different samples of maize in the stomach of pigs fitted with re-entrant duodenal cannulas. Hunt \& Knox (1972) have shown that an increase in the total acidity of the diet delays stomach emptying in man. If the greater acidity of diets preserved with organic acid delays stomach emptying, it is possible that salivary amylase may act for a longer time. It was found that the $\mathrm{pH}$ of the stomach contents of pigs receiving maize-soya-bean diets was higher than $4^{\circ} \circ$, except in the fundus, for up to $3 \mathrm{~h}$ after ingesting the meal (Bayley et al. 1974) and thus salivary amylase which is active above $\mathrm{pH}_{4}$ may have played an important role in the hydrolysis of starch in these diets.

* Present address: Beef Cattle Research Station, Erap, via LAE, Papua, New Guinea. 
Table 1. Composition ( $\mathrm{g} / \mathrm{kg}$ ) of diets used to compare dry, high-moisture ensiled, and high-moisture, acid-preserved maize

$\begin{array}{lr}\text { Ground maize (dry or equivalent high-moisture maize)* } & 750 \\ \text { Soya-bean meal (490 g crude protein } / \mathrm{kg}) & 200 \\ \text { Calcium phosphate }(174 \mathrm{~g} \mathrm{Ca}, 200 \mathrm{~g} \text { phosphorus } / \mathrm{kg}) & 15 \\ \text { Ground limestone }(380 \mathrm{~g} \mathrm{Ca} / \mathrm{kg}) & 10 \\ \text { lodized salt } & 5 \\ \text { Vitamin and trace mineral and chromic oxide mixture } \dagger & 20\end{array}$

* $900 \mathrm{~g}$ dry matter $/ \mathrm{kg}$ basis.

$\dagger$ Supplying the following amounts of nutrients $/ \mathrm{kg}$ diet: retinol acetate, $0.8 \mathrm{mg}$; cholecalciferol, $3.25 \mu \mathrm{g}$, DL- $\alpha$-tocopheryl acetate, $2 \mathrm{mg}$; cyanocobalamin, II $\mu \mathrm{g}$; riboflavin, $2.5 \mathrm{mg}$; calcium $\mathrm{D}$-pantothenate, I I $\mathrm{mg}$; nicotinic acid, I I $\mathrm{mg}$; choline chloride, I g; manganese, $50 \mathrm{mg}$; copper, ro $\mathrm{mg}$; iton, $80 \mathrm{mg}$; zinc, $50 \mathrm{mg}$; and $3 \mathrm{~g}$ chromic oxide.

\section{EXPERIMENTAL}

\section{Diets}

Physiologically mature maize (Stewart's variety 2606) was harvested in October $197 \mathrm{I}$ with a moisture content of $230 \mathrm{~g} / \mathrm{kg}$. One batch (for diet $\mathrm{I}$ ) was dried at $70^{\circ}$ for $3 \mathrm{~h}$ in a forced-air drier to a moisture content of $100 \mathrm{~g} / \mathrm{kg}$. Two other batches (for diets 2 and 3 ) were mixed in a large vertical food mixer with either acetic or propionic acids at the rate of $12.5 \mathrm{~g}$ acid/ $/ \mathrm{kg}$ maize and stored in plastic-lined, sealed, steel drums ( $570 \mathrm{~mm}$ diameter $\times 860 \mathrm{~mm}$ high). A fourth batch of maize (for diet 4 ) was ground and allowed to ensile naturally in plastic-lined, steel drums which were fitted with air traps during the ensiling process and subsequently sealed. The maize was stored until the summer of 1972 and microbiological examination showed that all four batches had been protected from spoilage by their respective preservation treatments.

The dry and acid-treated, high-moisture maize was ground before incorporation into the experimental diets. The composition of the diets is shown in Table $\mathrm{I}$; the amount of high-moisture maize in the diets was adjusted to supply the same quantity of dry matter as dry maize. The diets containing the high-moisture maize were stored at $5^{\circ}$ to prevent spoilage.

\section{Animals and their management}

Male castrate pigs, $30 \mathrm{~kg}$ live weight, were fitted with re-entrant duodenal cannulas as described by Holmes, Horney \& Leadbeater (1973). The gut was transected proximal to the opening of the pancreatic ducts and about $50-80 \mathrm{~mm}$ from the pylorus. The bile duct entered the duodenum within Io $\mathrm{mm}$ of the pylorus. The material collected from the cannula consisted of ingested food, saliva, gastric juice and bile together with their hydrolysis products. The animals were housed in metabolism crates and received water $a d l i b$.

\section{Design}

The pigs received two meals/d, each of $400 \mathrm{~g}$ dry-maize diet or the equivalent amount of the diets containing the high-moisture maize. The meals were offered at $12 \mathbf{h}$ intervals. A $6 \mathrm{~d}$ acclimatization period preceded the collection of duodenal digesta for 
$\mathrm{I} 2 \mathrm{~h}$ following the ingestion of a meal on the 7 th day. Each of the pigs received all four diets during the 4-week experiment.

In the first part of the experiment four pigs received each diet in a Latin-square design, but only fourteen of the planned sixteen collections were completed because of food refusals. The digesta samples were destroyed when the freeze-drier failed, therefore, the only values available from this part of the experiment related to the flow of digesta during the $\mathrm{I} 2 \mathrm{~h}$ collection period. The experiment was continued with the pigs which now weighed $40 \mathrm{~kg}$, but one pig developed total anorexia and was destroyed. The other three pigs completed the experiment, but only eleven of the planned twelve collections were completed, again because of food refusal. The results from this part of the experiment were analysed as a $4 \times 4$ Latin square with one missing row and a missing value as described by Yates (1936). There were 2 degrees of freedom for the error term; standard errors for each diet mean were calculated from the error mean square and are included in the tables where appropriate.

\section{Collection of duodenal digesta}

The procedure was similar to that described for ileal digesta by Holmes, Bayley \& Horney (1973). Flow was recorded at intervals varying from 15 to $60 \mathrm{~min}$ and a $10 \%$ subsample was retained, the remainder being returned to the pig. The subsample was acidified to $\mathrm{pH}_{2}$ with $6 \mathrm{M}$-hydrochloric acid to inactivate the salivary amylase, neutralized with I M-sodium hydroxide, frozen and stored at $-20^{\circ}$.

\section{Analytical methods}

The frozen digesta samples were freeze-dried. $\mathrm{N}$ was determined by the macroKjeldahl method. Glucose was determined using a glucose-oxidase procedure (Fisher Scientific, Toronto, Ontario, Canada). Starch was determined by the method of MacRae \& Armstrong ( 1968 ) using the glucose-oxidase procedure to measure the glucose liberated. In all instances the starch values refer to all the $\alpha$-linked polymers of glucose and are expressed as glucose equivalents. Chromic oxide was determined by atomic absorption spectrophotometry. The $\mathrm{pH}$ of the diets was measured on a slurry of $25 \mathrm{~g}$ of finely ground diet in $25 \mathrm{ml}$ deionized water. The total acidity (mequiv./g) was measured by titrating $5 \mathrm{~g}$ finely ground diet to $\mathrm{pH} 7$ with a solution of sodium bicarbonate $(20 \mathrm{mg} / \mathrm{ml})$.

\section{RESULTS}

The $\mathrm{pH}$ of the diet $\mathrm{r}$, containing dry maize, was $5 \cdot 85$, and those of diet 2 and 3 containing maize preserved with acetic or propionic acids respectively were 4.80 and 4.93 respectively. The value for diet 4 , the ensiled maize, was $5 \cdot 16$. The total acidities of the four diets were $0.47,0.71,0.83$ and 0.53 mequiv./g respectively. These results suggested that the organic acids added to the maize had not broken down during the 7 months of storage. 
Table 2. Total and cumulative proportions of duodenal flow (based on digesta volume only) in $\mathrm{I} 2 \mathrm{~h}$ period following ingestion by pigs of a meal containing dry or high-moisture maize preserved in different ways

(Mean values for four pigs/treatment)

\begin{tabular}{|c|c|c|c|c|c|c|}
\hline \multirow[b]{2}{*}{ Diet } & \multirow{2}{*}{$\begin{array}{l}\text { No. of } \\
\text { collections }\end{array}$} & \multirow{2}{*}{$\begin{array}{l}\text { Mean flow } \\
s \text { in I } h(1)\end{array}$} & \multicolumn{4}{|c|}{ Cumulative proportion of flow in $12 \mathrm{~h}$} \\
\hline & & & $0-3 \mathrm{~h}$ & $0-6 h$ & $0-9 \mathrm{~h}$ & $0-12 h$ \\
\hline I Dry maize & 7 & $4 \cdot 76$ & 0.41 & 0.70 & 0.90 & $I \cdot 00$ \\
\hline $\begin{array}{l}2 \text { High-moisture maize } \\
+ \text { acetic acid }\end{array}$ & 8 & $4 \cdot 6 \mathrm{r}$ & 0.41 & 0.63 & 0.78 & $\mathrm{I} \cdot \infty$ \\
\hline $\begin{array}{l}3 \text { High-moisture maize } \\
\text { + propionic acid }\end{array}$ & 8 & $4 \cdot 5^{8}$ & 0.35 & 0.66 & 0.83 & $I \cdot 00$ \\
\hline $\begin{array}{l}4 \text { High-moisture maize, } \\
\text { ensiled }\end{array}$ & 7 & $4 \cdot 60$ & 0.38 & 0.64 & 0.80 & $\mathrm{I} \cdot \infty \circ$ \\
\hline
\end{tabular}

Table 3. Dry matter ingested and collected from duodenal cannula in $12 h$ period following ingestion by pigs of a meal containing dry or high-moisture maize, preserved in different ways, with cumulative proportion of total flow in $3,6,9$ and $\mathrm{I} 2 \mathrm{~h}$

\begin{tabular}{|c|c|c|c|c|c|c|c|}
\hline \multicolumn{8}{|c|}{ (Mean values for three pigs/treatment) } \\
\hline \multirow[b]{2}{*}{ Diet } & \multirow{2}{*}{$\begin{array}{l}\text { Dietary } \\
\text { intake } \\
(\mathrm{g} / \mathrm{1} 2 \mathrm{~h})\end{array}$} & \multirow{2}{*}{$\begin{array}{c}\text { Total } \\
\text { duodenal } \\
\text { flow } \\
(\mathrm{g} / \mathbf{1} 2 \mathrm{~h})\end{array}$} & \multirow{2}{*}{$\begin{array}{l}\text { Proportion } \\
\text { of intake } \\
\text { in duo- } \\
\text { denal flow }\end{array}$} & \multicolumn{4}{|c|}{ Cumulative proportion of flow in $\mathrm{I} 2 \mathrm{~h}$} \\
\hline & & & & $0-3 h$ & $0-6 h$ & $0-9 h$ & $0-12 h$ \\
\hline I Dry maize & 356 & $3+3$ & 0.88 & 0.38 & 0.73 & $0.9 \mathrm{I}$ & $I \cdot 00$ \\
\hline $\begin{array}{l}2 \text { High-moisture } \\
\text { maize + acetic acid }\end{array}$ & 359 & 3II & 0.87 & 0.43 & 0.60 & 0.72 & 1.00 \\
\hline $\begin{array}{l}3 \text { High-moisture } \\
\text { maize + propionic } \\
\text { acid }\end{array}$ & $35^{8}$ & 340 & 0.95 & 0.43 & 0.73 & 0.85 & $x \cdot 00$ \\
\hline $\begin{array}{l}4 \text { High-moisture } \\
\text { maize, ensiled }\end{array}$ & $35^{8}$ & 3 I 4 & 0.88 & 0.36 & 0.57 & 0.76 & $I \cdot \infty 0$ \\
\hline Mean & 358 & 304 & 0.90 & & & & \\
\hline $\mathrm{SE}$ & - & I 8 & 0.04 & & & & \\
\hline
\end{tabular}

\section{Flow of digesta}

Approximately $4.5 \mathrm{l}$ of digesta were collected during the $\mathrm{I} 2 \mathrm{~h}$ period in the first part of the experiment (Table 2). A greater proportion of the total flow passed through the cannulas in the first $9 \mathrm{~h}$ of the collection from the pigs which received diet $\mathrm{r}$ than from the pigs which received the other diets. In the second part of the experiment approximately $5.25 \mathrm{l}$ of digesta were collected in the $\mathrm{I} 2 \mathrm{~h}$ period. The amounts of dry matter ingested and the amount passing through the duodenal cannulas are shown in Table 3. The amount of dry matter flowing through the duodenal cannulas was less than that ingested in the meal; between 0.87 and 0.95 of the ingested dry matter was measured in the duodenal flow. The differences between the four diets were not statistically significant. As in the first part of the experiment there was a greater flow in the first $9 \mathrm{~h}$ with diet $\mathrm{I}$ than with the other diets. 
Table 4. Composition ( $\mathrm{mg} / \mathrm{g}$ dry matter) of diets and duodenal digesta collected over a $12 h$ period following the ingestion by pigs of a meal containing dry maize or high-moisture maize preserved in different ways

(Mean values for three pigs/treatment)

\begin{tabular}{|c|c|c|c|c|c|c|}
\hline & \multicolumn{4}{|c|}{ Diet } & & \\
\hline & \multicolumn{4}{|c|}{ High-moisture maize } & & \\
\hline & $\begin{array}{c}\text { Dry } \\
\text { maize }\end{array}$ & $\begin{array}{c}+ \text { Acetic } \\
\text { acid }\end{array}$ & $\begin{array}{c}+ \text { Propionic } \\
\text { acid }\end{array}$ & Ensiled & Mean & $\mathrm{SE}$ \\
\hline \multicolumn{7}{|c|}{ Nitrogen } \\
\hline Diet & $3 \mathrm{I} \cdot 2$ & $3 I \cdot 0$ & $3 I \cdot 0$ & $3 r \cdot 8$ & $3 \mathrm{I} \cdot 3$ & \\
\hline Duodenal digesta & $32 \cdot 5$ & $28 \cdot 8$ & $26 \cdot x$ & $32 \cdot 4$ & 30.0 & 0.8 \\
\hline \multicolumn{7}{|c|}{ Starch* } \\
\hline Diet & 556 & 582 & 601 & 564 & 576 & \\
\hline Duodenal digesta & 330 & 393 & $35^{\circ}$ & 302 & 344 & 45 \\
\hline \multicolumn{7}{|c|}{ Glucose } \\
\hline Diet & 0.7 & $6 \cdot 3$ & $6 \cdot 7$ & $2 \cdot 5$ & $4 \cdot I$ & \\
\hline Duodenal digesta & $15 \cdot 6$ & $13 \cdot 4$ & 14.5 & $7 \cdot 9$ & I $2 \cdot 9$ & 0.8 \\
\hline \multicolumn{7}{|c|}{ Chromic oxide } \\
\hline Diet & $3 \cdot 0$ & $3 \cdot I$ & $3 \cdot 4$ & $3 \cdot 2$ & $3 \cdot 2$ & \\
\hline Duodenal digesta & $2 \cdot 6$ & $2 \cdot 9$ & $2 \cdot 7$ & $3 \cdot 2$ & $2 \cdot 9$ & 0.2 \\
\hline
\end{tabular}

\section{Composition of digesta}

The composition of the diets and duodenal digesta derived from these diets is shown in Table 4. The mean $\mathrm{N}$ contents of the diets and digesta were very similar, but there tended to be less $\mathrm{N}$ in the duodenal digesta derived from diets 2 and 3 (organic acidpreserved maize) than in the digesta derived from diets $\mathrm{I}$ or 4 (dry or ensiled maize) $(0.1>P>0.05)$. The mean value for starch in the duodenal digesta was much less than that in the diet, although there tended to be more in the digesta from diets 2 and 3 than in that from diets $I$ and 4 . The difference in mean starch concentration $(232 \mathrm{mg} / \mathrm{g}$ ) between the diet and duodenal digesta was much greater than the corresponding difference in glucose concentration $(8.8 \mathrm{mg} / \mathrm{g})$. Although diet $\mathrm{I}$ contained less than I mg glucose/g the digesta derived from this diet contained the highest level of glucose $(15.6 \mathrm{mg} / \mathrm{g})$. The digesta from diet 4 tended to contain less glucose than the digesta derived from the other three diets $(P=0 \cdot I)$. The mean concentration of chromic oxide in the duodenal digesta was less than that in the diet.

Combination of the results in Tables 3 and 4 allows a quantitative examination of gastric digestion. Table 5 shows that only 0.8 of the ingested $\mathrm{N}$ passed through the duodenal cannulas with diets 2 and 3 (organic acid-treated maize), whereas the corresponding figure with diets 1 and 4 was 0.9 . Only 0.54 of the ingested starch passed through the duodenal cannulas, but the value tended to be higher with diets 2 and 3 than with diets $I$ and 4 .

The mean flow of glucose through the cannulas was much less $(4 \cdot \mathrm{I} / \mathrm{I} 2 \mathrm{~h})$ than the 
Table 5. Dietary intake and duodenal flow $(g / 12 h)$ for pigs receiving a single meal containing dry maize or high-moisture maize preserved in different ways

(Mean values for three pigs/treatment)

\begin{tabular}{|c|c|c|c|c|c|c|}
\hline & \multicolumn{4}{|c|}{ Diet } & & \\
\hline & \multicolumn{4}{|c|}{ High-moisture maize } & & \\
\hline & $\begin{array}{c}\text { Dry } \\
\text { maize }\end{array}$ & $\begin{array}{l}+ \text { Acetic } \\
\text { acid }\end{array}$ & $\begin{array}{l}+ \text { Propionic } \\
\text { acid }\end{array}$ & Ensiled & Mean & $\mathrm{SE}$ \\
\hline \multicolumn{7}{|c|}{ Nitrogen } \\
\hline $\begin{array}{l}\text { Dietary intake } \\
\text { Duodenal flow } \\
\text { Recovery* }\end{array}$ & $\begin{array}{l}\text { II I I } \\
10 \cdot 2 \\
0.92\end{array}$ & $\begin{array}{l}\text { I I.0 } \\
9.0 \\
0.82\end{array}$ & $\begin{array}{l}\text { I I.0 } \\
8 \cdot 9 \\
0.81\end{array}$ & $\begin{array}{l}11 \cdot 3 \\
10 \cdot 2 \\
0.90\end{array}$ & $\begin{array}{l}\text { I I } \cdot \text { I } \\
9 \cdot 6 \\
0.86\end{array}$ & $\begin{array}{l}0.4 \\
0.03\end{array}$ \\
\hline \multicolumn{7}{|c|}{ Starch $\uparrow$} \\
\hline Dietary intake & 198 & 207 & $2 r_{4}$ & 201 & 205 & \\
\hline Duodenal flow & 103 & 122 & 119 & 95 & I 10 & 19 \\
\hline Recovery & 0.52 & 0.59 & 0.56 & 0.47 & 0.54 & 0.09 \\
\hline \multicolumn{7}{|c|}{ Glucose } \\
\hline Dietary intake & 0.25 & $2 \cdot 24$ & $2 \cdot 39$ & 0.89 & $x \cdot 5$ & \\
\hline Duodenal flow & $4 \cdot 88$ & $4 \cdot 17$ & $4 \cdot 93$ & $2: 48$ & $4^{\cdot} \mathrm{I}$ & 0.3 \\
\hline Recovery & 19.5 & $1 \cdot 88$ & $2 \cdot 06$ & $2 \cdot 79$ & $9 \cdot I$ & I.8 \\
\hline \multicolumn{7}{|c|}{ Chromic oxide } \\
\hline Dietary intake & I.07 & $I \cdot 10$ & $I \cdot 2 I$ & $I \cdot I_{4}$ & $1 \cdot 13$ & \\
\hline Duodenal flow & 0.89 & 0.90 & 0.93 & $1 \cdot 04$ & 0.94 & 0.08 \\
\hline Recovery & 0.83 & 0.82 & 0.79 & $0.9 \mathrm{I}$ & 0.84 & 0.09 \\
\hline
\end{tabular}

mean flow of starch ( $110 \mathrm{~g} / \mathrm{I} 2 \mathrm{~h}$ ), but the glucose content of the duodenal digesta was almost 20-fold higher than the amount ingested with diet $\mathrm{I}$ and with the other three diets was approximately twice the amount ingested. Only 0.84 of the ingested chromic oxide passed through the cannulas whereas the corresponding value for the ingested dry matter was 0.89 .

\section{DISCUSSION}

The finding that less of the ingested chromic oxide than of the ingested dry matter was present in the duodenal digesta, and the visual observation that the stomach contents were greener than normal, suggests that the chromic oxide separated from the rest of the diet and tended to rise to the upper oesophageal region of the stomach. A similar observation was reported by Carlson \& Bayley (1972) in younger pigs. Drennan, Holmes \& Garrett (1970) found that chromic oxide could not be used as a marker of digesta flux through the abomasum of sheep and cattle, apparently because the chromic oxide passed out of the rumen more rapidly than the other dietary components (Corbett, Greenhalgh \& MacDonald, 1958). In the ruminant, digesta leaves the rumen through the omasal orifice in the upper regions of the rumen whereas digesta leaves the stomach of the pig from its lower regions. Thus if chromic oxide rises to the top of the digesta, it would pass out of the rumen more quickly than the 
rest of the digesta, but it would pass out of the pig's stomach more slowly than the rest of the digesta.

The tendency for more of the duodenal digesta to pass through the cannulas in the first $9 \mathrm{~h}$ of the collection with the less acid, dry maize diet than with the organic acidtreated maize diets supports the observation of Hunt \& Knox (1972) that increasing the acidity of the diet delays stomach emptying. Riis \& Jakobsen (1969) found that mixing in the stomach of the pig is slow and may not be complete in $\mathrm{I} 6 \mathrm{~h}$, thus starch would be digested in the stomach under the influence of salivary amylase. Chauncey, Henriques \& Tanzer ( 1963 ) found that there was considerable amylase activity in pig saliva and thus dietary starch would be hydrolysed to maltose and isomaltose. These disaccharides are rapidly hydrolysed and absorbed in the small intestine (Fordtran \& Ingelfinger, I968), with absorption of glucose rather than hydrolysis of the disaccharides limiting the rate of the over-all process.

In our experiment an average of $95 \mathrm{~g}$ glucose equivalents of the ingested starch (Table 5) did not reach the duodenal cannulas, and there were only $2.6 \mathrm{~g}$ 'extra' glucose, thus a maximum of $92 \mathrm{~g}$ glucose was absorbed in the $12 \mathrm{~h}$ period (i.e. $7 \cdot 7 \mathrm{~g} / \mathrm{h}$ ). Fordtran \& Ingelfinger ( 1968 ) state that in man rates of glucose uptake of $0.053 \mathrm{~g} / \mathrm{mm}$ duodenum per $h$ have been recorded. Thus, unless the pig is capable of greater rates of glucose absorption than man, $150 \mathrm{~mm}$ of duodenum could accommodate this uptake provided that no glucose was absorbed from the stomach. These results were collected in the second month after installation of the cannulas. Thus it appears possible that almost half the ingested starch can be hydrolysed and absorbed anterior to the pancreatic duct. This is in marked contrast to the ingested $\mathrm{N}$ which nearly all passed through the duodenal cannulas.

It is noteworthy that the difference between dietary dry matter ingested and dry matter passing through the duodenal cannulas was $54 \mathrm{~g}$ (Table 3 ) and this difference may be the result of absorption of glucose before the digesta reached the cannulas.

It is also possible that bacterial fermentation was responsible for converting the starch to volatile fatty acids in the stomach. Friend, Cunningham $\&$ Nicholson (I963) found $\mathrm{x} 6 \mathrm{~g}$ organic acids in the stomach of pigs of $70-100 \mathrm{~kg}$ live weight which were slaughtered $6 \mathrm{~h}$ after feeding. Although no estimate of total organic acid production or of the food intake of these pigs was given it is clear that a high level of fermentation can take place in the stomachs of large pigs. They found acidities of 150 mequiv. $/ 1$ for the large pigs but only $6-\mathrm{I} 6$ mequiv. $/ 1$ ( $0 . \mathrm{I}-0.2 \mathrm{~g}$ of total organic acids) for smaller pigs $(20 \mathrm{~kg})$. In view of the antibiotic properties of the acetic and propionic acids used to preserve maize in diets 2 and 3 in our study, fermentation probably would not account for more than a small part of the starch digestion.

This study has shown that digestion in the stomach makes an important contribution to the total hydrolysis of starch in pigs receiving two meals of a maize-soya-bean diet/d; up to half the $\alpha$-linked glucose polymers disappeared from the digestive tract before the digesta reached the pancreatic ducts in the duodenum. In contrast little or no $\mathrm{N}$ disappeared before the digesta reached the pancreatic ducts. Preservation of the high-moisture maize with organic acids increased the total acidity of the diet and tended to delay stomach emptying, but there was no evidence that this resulted in 
any increase in starch hydrolysis in the stomach. However, the delay in stomach emptying meant a more uniform flow of digesta through the small intestine over the I $2 \mathrm{~h}$ periods between the two daily meals. This could explain the observation of Holmes et al. (1973) that both the starch and $\mathrm{N}$ were removed from the small intestine more completely from the acid-preserved maize diet than from the dry maize diet.

It appears that processing foods in different ways not only modifies the extent to which the food is amenable to digestion and absorption in the animal's digestive tract but can also alter the response of the animal's digestive tract to the ingestion of food. In the present instance, adding organic acids to the maize improved the digestive utilization of diets containing the acid-treated maize by slowing the rate of passage of the digesta.

This work was supported by a research grant from Celanese (Canada) Ltd, Edmonton, Alberta. The authors are grateful to Dr G. C. Ashton for his advice on the statistical analysis of the results.

\section{REFERENCES}

Bayley, H. S., Holmes, J. H. G. \& Stevenson, K. R. (1974). Can. F. Anim. Sci. 54.

Carlson, W. E. \& Bayley, H. S. (1972). Br. Y. Nutr. 28, 295.

Chauncey, H. H., Henriques, B. L. \& Tanzer, J. M. (1963). Archs oral Biol. 8, 6r 5.

Corbett, J. L., Greenhalgh, J. F. D. \& MacDonald, A. P. (1958). Nature, Lond. 182, 1014.

Drennan, M. J., Holmes, J. H. G. \& Garrett, W. N. (1970). Br. Y. Nutr. 24, 96r.

Fordtran, J. S. \& Ingelfinger, F. J. (1968). In Handbook of Physiology: Section 6, Alimentary canal Vol. 3, p. 1457 [C. F. Code, editor]. Washington, DC: American Physiological Society.

Friend, L. W., Cunningham, H. M. \& Nicholson, J. W. G. (1963). Can. F. Anim. Sci. 43, I 56.

Holmes, J. H. G., Bayley, H. S. \& Horney, F. D. (1973). Br. $¥$. Nutr. 30, 401.

Holmes, J. H. G., Horney, F. D. \& Leadbeater, P. A. (1973). Am. F. vet. Res. 34, I365.

Hunt, J. N. \& Knox, M. T. (1972). F. Physiol., Lond. 222, 187.

MacRae, J. C. \& Armstrong, D. G. (1968). F. Sci. Fd Agric. 19, 578.

Riis, P. M. \& Jakobsen, P. E. (I 969). In Nutrition of Animals of Agricultural Importance Part I, p. I49 [D. Cuthbertson, editor]. Oxford: Pergamon Press.

Yates, F. (1936). F. agric. Sci., Camb. 26, 301. 